Research, part of a Special Feature on Programme on Ecosystem Change and Society (PECS): Knowledge for Sustainable Stewardship of Social-ecological Systems

\title{
Stakeholder engagement and biodiversity conservation challenges in social- ecological systems: some insights from biosphere reserves in western Africa and France
}

\author{
$\underline{\text { Meriem Bouamrane }}^{1}, \underline{\text { Marja Spierenburg }}^{2}, \underline{\text { Arun Agrawal }}^{3}, \underline{\text { Amadou Boureima }}^{4}, \underline{\text { Marie-Christine Cormier-Salem }}^{5,6}, \underline{\text { Michel Etienne }}^{7}$, \\ Christophe Le Page $^{8}$, Harold Levrel $^{9,10}$ and Raphael Mathevet ${ }^{11}$
}

\begin{abstract}
Biosphere reserves are an example of social-ecological systems that combine biodiversity conservation and socioeconomic development with knowledge generation and dissemination (both scientific and local). We review lessons learned from case studies biosphere reserves in western African and France, highlighting the importance of early stakeholder engagement to build knowledge for achieving sustainable development. We discuss the evolution of the concept of biosphere reserves and its application over time in different socioeconomic and cultural settings. The diversity of stakeholders and their different needs and perceptions about nature conservation complicate implementation processes, sometimes resulting in conflicts about the objectives and zonation of biosphere reserves. Dialogue among the different stakeholders must start at an early planning phase and be based on the principle of social and ecological solidarity. Dialogue must then be pursued, formalized, ritualized, and translated both in terms of biosphere reserve management and in terms of political support. Tools and methods exist that can facilitate such dialogue and colearning.
\end{abstract}

Key Words: biosphere reserves; learning; social-ecological systems; solidarity; sustainable development

\section{INTRODUCTION}

Social-ecological systems (SESs) are defined as interdependent and linked systems of people and nature that are nested across scales (Folke 2006, Ostrom 2009). Biosphere reserves are conceived as examples of sustainable SESs. These specific places are designed to combine biodiversity conservation with socioeconomic development and knowledge production (both scientific and local) and dissemination (UNESCO 1996). They provide a diversity of learning opportunities and management practices for sustainable development, especially because they often result in emergence of new institutions and networks. Indeed, in a large number of countries, biosphere reserves are considered reference landscapes for testing innovative approaches to sustainable development. There are many examples of how they can be and are used for monitoring SESs, for participatory approaches to conservation with local communities, and for combining scientific and local knowledge (Bouamrane 2006, Mathevet et al. 2011, Shultz et al. 2011). However, the implementation of the biosphere reserve concept is somewhat uneven, and especially some of the older sites often experience problems in combining the different key functions, and often focus mostly on the conservation function. The long experience of biosphere reserves provides an opportunity to understand better the key social and ecological processes that either lead to or hamper building engagement and knowledge to achieve sustainable development in SESs. Here, we focus on different experiences of performance, sharing lessons learned from biosphere reserves in West Africa and France, and discussing the importance of stakeholder involvement in determining the success of biosphere reserves. We also propose some tools and models to improve stakeholder involvement, based on these various cases.
We begin by reviewing the initial objectives of the Man and the Biosphere (MAB) program of the United Nations Educational, Scientific, and Cultural Organization (UNESCO) and the conception of the biosphere reserve project. We then proceed with a discussion of the different case studies, focusing on stakeholder engagement, governance, and knowledge production. Based on ongoing practices and research in West Africa and southern France, we discuss the conditions, principles, and values that favor positive interactions between conservation and development that may enable societies to maintain and create more options for present and future generations. These two regions were selected because they represent different socioeconomic contexts; our aim was to include experiences from so-called developing countries. Research for the case studies was conducted by some of the authors. Data were gathered through in-depth interviews with (representatives of) the main stakeholders involved in the biosphere reserves, focus group discussions, and participatory observations during stakeholder workshops (in some cases, organized by the researchers). Some cases also involved actionresearch, through which, for instance, participatory monitoring systems were cocreated with stakeholders.

\section{BIOSPHERE RESERVES: FROM CONSERVATION TO SUSTAINABLE DEVELOPMENT}

Since the creation of the first biosphere reserve in 1976, the concept and land-use management tool has evolved considerably on the ground. Biosphere reserves were created in a context when conservation, often referred to using the term "protection," was considered to be opposed to development, and the notion of sustainable development was not yet formulated (Ghimire and Pimbert 1997, Cormier-Salem 2006). 
Ecosystems support societies and economic systems, but by taking their existence and services as an exogenously given constant, human decision-making often ignores or underplays the importance of ecosystems (Weber 2013). Ecosystems are the basis of life, and "business as usual" in economic and social decision-making has brought many ecological and environmental processes closer to collapse (MEA 2005, Weber 2013, HomerDixon et al. 2015). The challenge remains to reconcile conservation and sustainable use of biodiversity within a given area and for a sustainable period of time. This is the founding and explicit goal of the biosphere reserve tool (Batisse 1986, UNESCO 1996). The biosphere reserve concept explicitly entails "....securing ecosystem services for human well-being" (UNESCO 2008:8). The sites are promoted as "learning sites" to explore innovative ways of fostering sustainable development.

The first sites designated (i.e., in 1976) were selected mainly on the basis of their biodiversity values and capacity to support protection and conservation, research, and monitoring (CormierSalem 2006, Ishwaran et al. 2008, Schultz et al. 2011). However, an important change took place with the adoption of the Statutory Framework and the Seville Strategy in 1996 (UNESCO 1996), which stipulated that all biosphere reserves were expected to fulfill all three of the following functions: (1) conserving biodiversity; (2) fostering sustainable social and economic development; and (3) supporting research, monitoring, and education (UNESCO 1996, Schultz et al. 2011, Bridgewater 2016). These three functions were to be implemented through a (at the time) very innovative land management approach, with a zonation system consisting of three zones: a core area devoted to conservation, buffer zones to minimize impacts on the core area, and a transition area to maintain development and human settlement. Since 1996, the emphasis has been put more firmly on sustainable development in biosphere reserves, stressing the importance of innovative combinations of conservation, development, and learning while taking account of processes at different temporal and spatial scales. The Seville Strategy highlighted the role of biosphere reserves as platforms for exchange and experimentation, providing the possibility of permanent interactions between society and ecosystems, through continuing negotiations and dialogue among relevant actors on their vision of a common future (Batisse 1982, UNESCO 1996, Bouamrane 2006, 2007). It implies a process of active participation of diverse stakeholders working together in concert to develop a unified proposal or common focus (in terms of visions, objectives, points of view, and concerted action). Around the same time, the development of biosphere reserves was taken a step further through the creation of the first transboundary biosphere reserves in Europe, soon followed by the establishment of similar transboundary sites in Africa and Latin America. These were created as a means to implement dialogue and effective conservation beyond national boundaries.

In practice, however, the World Network of Biosphere Reserves shows some unevenness, with some sites demonstrating truly innovative attempts to foster sustainable development and comanagement, whereas others, especially older sites, are more conventional protected areas focusing mainly on biodiversity conservation and involving fewer stakeholders (Schultz et al. 2011, Ruiz-Mallén et al. 2015, Bridgewater 2016). More recently, however, UNESCO has become stricter about conditions for the designation of biosphere reserves, and is implementing an exit strategy for those sites that do not meet the Statutory Framework criteria (UNESCO 2013). For these sites, countries are requested to submit periodic review reports and submit detailed plans to upgrade the site so that it will meet all the criteria. Countries are invited to withdraw the site if it does not meet the criteria within a period of 30 months after the beginning of the implementation of the exit strategy (UNESCO 2013). Should the MAB International Co-ordinating Council find that the biosphere reserve still does not satisfy the criteria, the area will no longer be referred to as a biosphere reserve part of the World Network (UNESCO 1996). Several sites that did not meet the criteria have actually been withdrawn from the World Network by countries, including Germany, Austria, Australia, UK, and Norway.

\section{DIALOGUE AND STAKEHOLDERS' ENGAGEMENT IN BIOSPHERE RESERVES: A NECESSARY STARTING POINT}

These changes in the management of the World Network of Biosphere Reserves parallel more general debates about the relations between protected areas (e.g., national parks) and resident and neighboring communities in general. Discussions about the need to combine conservation with (local) development and participatory approaches gained prominence in the mid-1980s. The "fines-and-fences" or "fortress" approach to conservation was deemed unsuccessful in fostering conservation goals (Hulme and Murphree 2001). Arguments to promote more participatory approaches ranged from the more pragmatic concerns, i.e., people will be more supportive of conservation if they receive benefits from conservation and participate in decision-making (Stoll-Klemann and O'Riordan 2002, Colfer 2005), to social justice concerns. Especially in the Global South, protected areas were quite often the result of evicting local resource users (Ramutsindela 2004, Hutton et al. 2005, Brockington and Igoe 2006, Brockington et al. 2006), and this has also been the case for some of the early biosphere reserves in the Global South. Community-based natural resource management and benefit sharing were supposed to redress these legacies from the past and diminish conflicts between conservation authorities and local residents. A number of pioneering projects to this end were developed in the late 1980s and 1990s (Hulme and Murphree 2001, Adams et al. 2004). More recently, the development of the concept of ecosystem services, its linkages with human well-being, and the increased awareness that ecosystems and societies are interdependent and constitute SESs that are complex and adaptive (Berkes and Folke 1998, Schultz et al. 2011, Fischer et al. 2015) also serve to underpin participatory approaches to conservation.

Although a global assessment conducted by Oldekop et al. (2016) shows that community involvement in managing protected areas results in positive effects on biodiversity outcomes, conservation authorities still appear to be hesitant about sharing management responsibilities with local residents. A number of studies have documented how participatory approaches have become a dominant discourse within biodiversity conservation, yet often these are only paid lip service. Many scholars point to the lack of actual transfer of decision-making powers to local resource users and demonstrate that biodiversity concerns still overrule developmental concerns in many so-called participatory conservation initiatives (Chapin 2004, Ribot and Larson 2005, Dressler et al. 2010, Cormier-Salem 2014). 
Looking at the World Network of Biosphere Reserves, many of older, more conventional sites are all or part of national parks and are located in the Global South, and similar critiques could apply to those as well. However, the adoption of the Seville Strategy and Statutory Framework (UNESCO 1996) has created room for change in a number of biosphere reserves. Many of the proposals that led to some controversy among conservationists initially came from member states in the North, but recently, more experimental approaches are also emanating from countries in the South. The objective of conservation is no longer considered opposed to human activities. In some sites, the conservation objective is actually dependent on the maintenance of human practices that shaped the ecosystems (i.e., Cevennes Biosphere Reserve in France, Cat Ba Biosphere Reserve in Vietnam, and Inlay Lake Biosphere Reserve in Myanmar) and actively strive to include all stakeholders in the management of the sites.

Building dialogue among the stakeholders appears to be one of the preliminary conditions needed to set up biosphere reserves and manage them from a sustainable development perspective. This need for dialogue appears repeatedly in the recommendations listed under the major goals of the Seville Strategy. Dialogue must begin as soon as possible (BorriniFeyerabend and Hamerlynck 2010), before any decisions are made concerning the creation of a biosphere reserve. It is essential to ensure that all options remain open when the dialogue starts, and that the possible scenarios for the future management of the area are not fixed in advance.

The implementation of the biosphere reserve concept is not a straightforward process. The concept is implemented in many different contexts, embedded in different socioeconomic and governance arrangements; (power) relations between the various stakeholders affect the implementation as well (Schultz et al. 2011, Ruiz-Mallén et al. 2015). The diversity of stakeholders and their needs and perceptions of nature conservation complicate implementation processes, sometimes resulting in conflicts about the zonation of biosphere reserves, as the case presented next demonstrates.

\section{SOME INSIGHTS FROM WEST AFRICA: DIALOGUE, BOUNDARIES, AND SCALES}

We discuss two examples in West Africa, which were selected because they are both transboundary sites and used to be national parks with strong constraints: the Région W Transboundary Biosphere Reserve (WTBR; in Benin, Burkina Faso, and Niger) and the Delta du Fleuve Senegal Transboundary Biosphere Reserve (RBTDS; in Mauritania and Senegal). Both were established around previously designated national parks, which were designated as the core areas, where strict protection principles are applied. However, in the process of extending them across national boundaries, a comanagement process was adopted, involving numerous information and consultation workshops with all the actors and stakeholders. The key messages emanating from these workshops concern the necessity of taking into account solidarities between the countries concerned, and of designing an innovative zonation that is more respectful of the dynamic of the SESs, notably the mobility of animals and people across the boundaries (see also Borrini-Feyerabed and Hamerlynck 2010).
The WTBR, designated in 2002, is well preserved despite the scarcity of resources and the high demand from local communities for resources located in the core area. Transboundary transhumance is one of the main challenges for management of biosphere reserves in West Africa. Transhumance patterns toward the WTBR are linked to droughts and insecurity in grazing in the Sahelian area. Transhumance is dynamic and shaped by new social networks as well as the dependence of the cattle on new grazing (Amadou and Boutrais 2012). The answer that the biosphere reserve offers to these new practices stemming from irreversible natural conditions (climate change) or from slow changes in the behavior of societies (for instance, an increase in both cattle and local community populations) seems to be inadequate because of the lack of flexibility of land management. The predefined zonation is working against the mid- and longterm existence of these protected areas. Local, national, and international legislative tools are based more on restriction and protection than on solidarity and sharing of resources among a diversity of actors.

The dynamic context of biosphere reserves in the SudanoSahelian region implies the need for a change in the conservation system to take into account the local, national, and regional contexts, including the level of poverty of local communities, their practices, the decentralization aspects, and the international norms and regulations regarding biodiversity conservation. It is therefore absolutely necessary to identify, based on local conditions, space for dialogue to reflect on the interactions between the different users and the protected areas. The understanding of the various objectives linked to use and management of resources and ecosystems by several stakeholders will facilitate the creation of social solidarity, sharing of resources, and maintenance of a peaceful atmosphere in a context of high pressure on resources and low ecosystem production (Amadou 2006, Bouamrane 2006, Deldicque 2007).

The RBTDS was designated by UNESCO in 2005. This site is based on a zonation system that combines protected areas as core areas (including the National Parks of Djoudj, Diawling, Langue de Barbarie, and Ndiael), buffer zones (including the Guembeul Reserve and Mpal forest), and transition areas where local dwellers (cultivators, fishermen, herders) are recognized as the main users and managers of the resources (Fig. 1). Despite the innovative feature of this model in terms of sustainable development and participatory governance, its legitimacy and efficiency are subject to debate (Cormier-Salem 2014). Among these debates, we focus here on the delimitation and zonation of this territory that does not take into account the migrations of fauna and people at various scales.

Migration of the waterfowl that gives its character to the RBTDS (the logo of the Djoudj National Birds Sanctuary is a pelican) is a good example of interconnections between diverse habitats from global to local scales (Fabre et al. 2016; M. Fabre, B. Ba El Abass, M.-C. Cormier-Salem, and S. Duvail, unpublished manuscript). At the global scale, most of the waterfowl (black tern, ducks, passerines, herons) migrate from Europe to Africa during the boreal winter. During their stay in the RBTDS, more or less from November to April, the bird species feed, moult, and reproduce in the national parks; however, most of them frequent habitats outside the limits of the RBTDS, in particular to feed. The vast 
rice fields that adjoin the Diawling and the Djoudj Parks are particularly attractive zones for granivorous birds. At a national scale, according to the season and water levels of the waterbodies, some species move from the Djoudj to the Guembeul Special Reserve along the coast. This special reserve has been designated as a Ramsar site as a complementary wetland of the Djoudj, and the management of the sites should be linked (Ramsar: http:// www.ramsar.org/wetland/senegal). At the scale of the Djoudj, where there are diverse waterbodies (marshes colonized by aquatic Typha australis and Phragmites australis or nenuphar, shallow open waterbodies, etc.), water birds adapt their strategies of migration from one waterbody to another according to the food abundance, tranquility, and water levels.

Fig. 1. Map of the Delta du Fleuve Senegal Transboundary Biosphere Reserve in 2005. Conceived and designed by M.C. Cormier-Salem; illlustrated by L. Billaut.

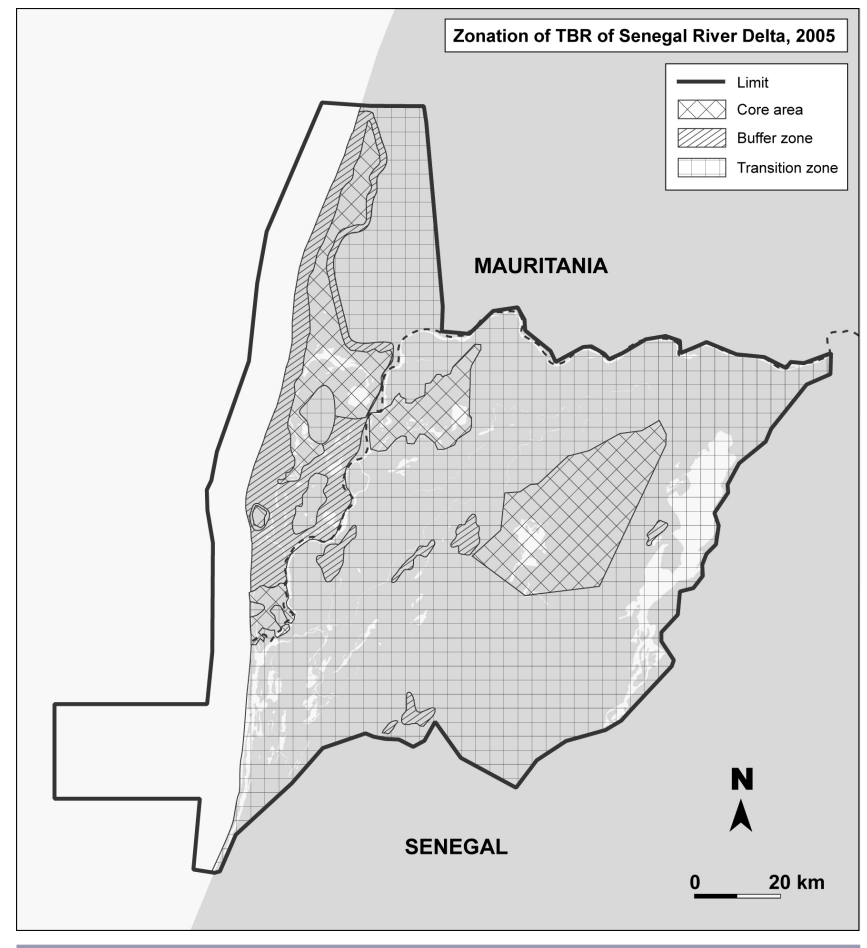

These strategies of migration inside and outside the RBTDS are very important for both wildlife (waterfowl, marine turtles, fish, ungulates) and domestic animals (herds of cattle or camels), as well as for the main users of these resources and spaces, the herders and sea fishers (Cormier-Salem 2006). For these actors, mobility is more than a strategy; it is a way of life. They used to circulate freely between both banks of the Senegal River before the establishment of the national borders. The scarcity of the resources and the environmental degradation linked to the successive droughts through the 1970s and 1980s, combined with the drastic effects of the public policies (the creation of national parks and reserves; construction of the Diama and Manantali dams, which are big hydro-agricultural developments) contributed to exacerbate injustices. The tensions that erupted in 1989 between Moors and Senegalese reveal conflicts of access to the resources. The creation of the RBTDS in 2005 was considered a means to solve those conflicts and reestablish solidarities beyond the boundaries.

The settlement of boundaries and the zonation process for establishing biosphere reserves highlight the need to take into account dynamic interactions between different spaces and resource use and access. In the West African case studies, the concerned resources are mobile and are subject to different uses as well as conflicts, depending on the stakeholders' needs and the season. To account for these flows and dynamics, there is a need to go beyond continuous and contiguous spaces that are more or less closed with fixed boundaries and to rethink these spaces as corridors, networks, or paths (Cormier-Salem 1995). Such open spaces with flexible and extensive borders as conceived by the users (fauna as well as people) are, however, influenced by specific places, their links, and interactions (for instance, bodies of water and grazing areas for wild fauna and cattle in the WTBR; the nestling and reproduction areas for marine turtles, waterfowl, or fish in the RBTDS). Moreover, these moving territories or paths are controlled by the nomadic communities, i.e., the herders in the WTBR or the fishers on the West African coast, who know their properties and are able to anticipate the climatic and environmental risks, and thus, adapt their spatial strategies to the changes. To reflect the dynamics of SESs and the point of view of local actors, a participatory approach has been put in place to propose a new governance model for the RBTDS. Field surveys and consultation workshops have led to the proposal of a new zonation plan, highlighting three major social-ecological units: a coastal unit centered on marine resources and fishers; a central unit on the Senegal River, including farmers (irrigated farming systems); and a southeastern unit on the wetland, including pastoralist herders (Fig. 2).

As emphasized by Schlosberg (2013), environmental justice comprises three interrelated dimensions: distribution of direct and indirect benefits from natural resources; procedure relating to decision-making; and recognition of culture, knowledge, and needs of different groups in those processes. In the two case studies presented above, the creation of protected areas and the resulting loss of access to resources by local communities, and especially the initial lack of dialogue and involvement of stakeholders, and the ignorance of local knowledge and practices, boundaries, and spatial discontinuities have created environmental injustices and explain the difficulties in shifting from a national park paradigm to a biosphere reserve paradigm. In both cases, despite good intentions and diverse incentives for implementing local development and attracting tourists, at this stage, the losers are the local communities (Cormier-Salem 2014).

\section{CREATING CONDITIONS FOR BUILDING AND SHARING KNOWLEDGE ABOUT SOCIAL- ECOLOGICAL INDERDEPENDENCIES: USE OF COMPANION MODELLING BIOSPHERE RESERVES IN FRANCE}

Dialogue must be pursued, formalized, ritualized, and translated both in terms of biosphere reserve management and in terms of political support. Biosphere reserves in France provide interesting experiences with the emergence and adaptation of methods of dialogue between researchers and stakeholders (Etienne 2006) inspired by the companion modeling (ComMod) approach. Developed in the 1990s by researchers from CIRAD (Centre de 
Fig. 2. Map of the Delta du Fleuve Senegal Transboundary Biosphere Reserve proposed in 2010. Conceived and designed by M.C. Cormier-Salem; illlustrated by L. Billaut.

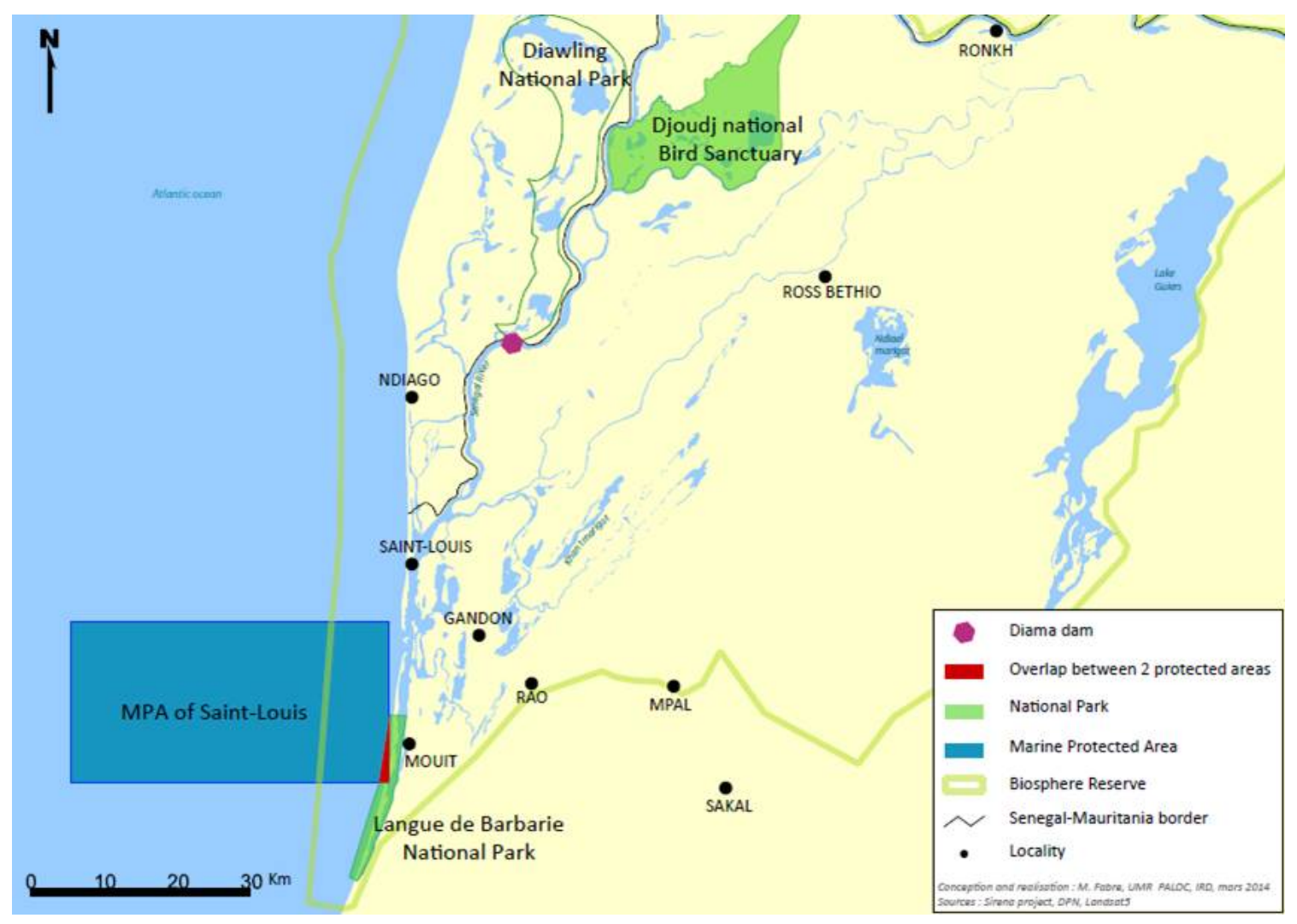

Coopération Internationale en Recherche Agronomique pour le Développement; Bousquet et al. 2002, Collectif ComMod 2005), this approach aims at identifying the various points of views and knowledge that local actors implicitly refer to and use in their relationship with their environment, working out a common vision of a given SES and its social-ecological interdependencies while combining scientific, local, and indigenous knowledge (Mathevet et al. 2016). We next investigate how the approach was used to support the recent designation process of the Gorges du Gardon Biosphere Reserve in 2016 in southern France. Contrary to the cases discussed above, local stakeholders were involved from the start. The process consisted of the following steps:

1. The Syndicate of the Gorges du Gardon (SGG; a joint association of local authorities that manage the Gorges du Gardon) asked for the support of the French MAB national committee to involve civil society and the population in elaborating the project. A range of different participatory tools were proposed, and the approach was implemented through the following agenda: a meeting between the MAB national committee and the SGG technicians to clarify the ins and outs of a biosphere reserve and share the representations of the territory and of the MAB concept with the members of the team.

2. A series of public meetings for exchanging information about the MAB program and the World Network of Biosphere Reserves took place in each of the municipalities covered by the SGG in the presence of the coordinator of a neighboring biosphere reserve and a member of the French MAB national committee, who shared their knowledge and experiences.

3. A series of meetings at inhabitants' homes were organized by volunteers to discuss the project of the creation of the biosphere reserve in a more friendly and free environment.

4. A town-hall meeting was organized with $\sim 100$ representatives of local stakeholders and the local administration to identify the territory and the main trends of evolution and to clarify and share the major stakes and principal actions to be undertaken.

5. Two ARDI (actors, resources, dynamics, and interactions) workshops were organized with specific stakeholders to coconstruct a shared representation of the interactions between society and nature in relation to farming activities and urban development.

6. A workshop was organized to clarify the state of the knowledge on these stakes and select relevant topics for research, development, conservation, awareness raising, and implementation of educational programs.

7. A final working session was organized to specify the zoning of the proposed biosphere reserve and the modalities of its governance. 
Throughout the process, regular information was disseminated via a biannual bulletin distributed to all the mailboxes of the local population.

The presence of researchers skilled in the use of participatory approaches and wishing to estimate their efficiency and transferability was an important starter in the dialogue process. However, it also needed the support of a strong local political will to implement participatory approaches. The desire of the SGG to keep control over the whole process was balanced by its will to leave the methodological options open, as well as the sequence of initiatives and the analysis of the outputs from the participatory workshops. During the process, power relations between multiple stakeholders had to be managed, as well as tensions among elected representatives with different political backgrounds, between different conservation initiatives (biosphere reserve, regional natural park, etc.), city and countryside, and the different UNESCO designations (World Heritage Site vs. Biosphere Reserve).

Many different types of knowledge needed to be balanced during the process: statutory knowledge (UNESCO criteria, urban planning, and the European Common Agricultural Policy regulations), methodological scientific knowledge (participatory approaches), thematic scientific knowledge (history, economy, sociology, ecology, agronomy), technical knowledge (livestock breeding, vine growing, hunting, climbing, kayaking), and experiential knowledge (practices of the users). This generated a diversity of learning experiences concerning the current stakes and trends (collective exploration of social-ecological interdependencies, dynamics, and complexity of the SES), on techniques allowing the attainment of a desired system state, about other participants (interests, stakes, skills, constraints, norms, and values), and on organization (collaborative workshops, cowriting).

The most difficult issue was about the legitimacy of the SGG and of the researchers involved in the different steps of the process. The legitimacy of the SGG to inform the inhabitants of the municipalities did not appear to be questioned, and it was obvious that administrative complications needed to be taken into account when broadening the debate to include all relevant administrations and consular chambers in the region. Choosing representatives from agriculture or various recreational bodies, or representatives of the citizens from each municipality, however, was less straightforward. For the researchers, the main issue was their double identity as a specialist of a specific discipline and as a member of an "administrative" committee. Confusion also sometimes resulted from shifting between their roles as facilitators of the participatory process and providers of scientific knowledge.

A similar approach to facilitate dialogue for a better understanding of social-ecological dynamics was implemented in the Delta du Rhone (Camargue) Biosphere Reserve in southern France. Inspired by the companion modeling approach to foster social learning among stakeholders about multiple-use management strategies, the social-ecological interdependencies and cooperative interactions between hunting managers and rice farmers of the Rhone Delta were represented in a spatially explicit, agent-based model. With the aim of evaluating multipleuse management strategies for wetland ecosystems (Mathevet et al. 2003b), this model allowed for the exploration of several scenarios based on contrasting water management schemes and on various modes of harvesting Mediterranean reed beds to support a collective evaluation of the long-term effects on avifauna, especially purple heron (Ardea purpurea), Eurasian bittern (Butorus stellaris), and reed warblers (Mathevet et al. $2003 a$ ). In a second stage of the participatory evaluation, a roleplaying game was designed and used to put stakeholders as players in close-to-real situations. The goal was to improve open communication and dialogue between a range of different stakeholders with highly diverse interests, including conserving high biodiversity levels and ecosystem services, maintaining a good human quality of life, and strengthening a local economy based on natural and cultural heritage (Mathevet et al. 2007). A role-playing game was created based on the agent-based modeling that allowed for the simulation of effects of multiple uses of a wetland on habitat and fauna dynamics (Mathevet et al. 2007). The role-playing tool is also used for training graduated students in dialogue and participatory management of both protected and nonprotected natural areas. It is also used with local stakeholders in several other Mediterranean wetlands. Results demonstrate that this tool fosters cognitive learning, collaboration, and critical thinking among many types of participants.

Bearing in mind the difficulties embedded in power relationships and equity issues of all participatory approaches (Barnaud et al. 2011, Voß and Bornemann 2011), developing a companion modeling approach as described above is useful for collective learning and for achieving forms of cooperative interactions. It is a constructive and constructivist approach that highlights the various interpretations of the SES by the actors according to their norms and values (Daré et al. 2011). Such approaches and tools may be mobilized and used at various points during a biosphere reserve's itinerary: when it is created, during periods of conflict, and every 10 years when the biosphere reserves are subject to periodic review in accordance with the Statutory Framework. Participatory approach facilitators should bear in mind that biosphere reserves are about humans and are designed for humans to live in them. Despite a widespread loss of both cultural and biological diversity, many biosphere reserves represent possible models for considering the relation of people with nature and reinforcing a sense of place or a principle of solidarity between humans and nature.

\section{CONCLUDING REMARKS: RETHINKING HUMAN- NATURE INTERDEPENDENCIES TOWARD SOLIDARITY}

The term biosphere reserve is not only a designation or an international recognition, it is first a long-term commitment, a responsibility, a social, economic, and ecological project, that must be supported and carried out by its inhabitants. The case studies presented here demonstrate that biosphere reserves can be sustainable development territories, and not be perceived as protected areas excluding people, when they implement their values and principles from the outset. A sincere dialogue requires the competencies of the stakeholders involved. Methods and practices must be provided for these stakeholders when it comes to dialogue, conflict prevention, and management. Methods and practices that have been applied successfully need to be shared more effectively. 
Conservation in a biosphere reserve should be open, interacting with the broader region with which it is connected. Unfortunately, many biosphere reserves are associated with parks or protected areas and thus have failed to put this "open concept" into practice (UNESCO 2002), creating misunderstanding, lack of support, and conflicts with inhabitants and local stakeholders.

Collective construction (or coconstruction) and collective learning are the foundation for establishing a biosphere reserve and maintaining its sustainable management. The development of collective rules governing access to and management of the resources in a biosphere reserve, the division of the territory into central area(s), buffer zone(s), and transition area(s) (zonation) should be the result of stakeholders' negotiations about means of access and uses of resources and ecosystems. The challenges of dialogue and engagement within a biosphere reserve would thus be to ensure greater respect for collective rules and lower enforcement costs; the joint implementation, by the management authority and stakeholders, of management rules; and the sharing of costs and benefits of programs or projects (Bouamrane 2006). Dialogue and coordination in a biosphere reserve should make it possible to reach a compromise between those who wish to conserve the resources and those who live off them, making it possible to ensure the future and find a shared focus based on a sustainable development objective.

Creating and managing a biosphere reserve is to reconcile, in the same space, conservation and economic development objectives and foster the convergence of the long-term interests of the stakeholders involved. Among all the conservation strategies, there are some that favor development, and among all the development strategies, there are some that favor conservation. The trajectory to be followed in a biosphere reserve lies at the point where these two sets of strategies intersect.

Biodiversity conservation and sustainable development are occurring in a context of uncertainty. To deal with uncertainty, we need to promote and explore collectively (throughout participatory processes and modeling) social and ecological interdependencies (Mathevet et al. 2010). By doing so we may shift from the concept of interdependence to ecological solidarity that highlights the community of fate between humans, their societies, and the rest of nature (Mathevet et al. 2016). Within a biosphere reserve, to take into account the ecological solidarity and to preserve it, there is a need to explore and discuss its local specificities and its related forms of attachment. Collectively exploring ecological solidarity is a pragmatic way to increase the resilience of biosphere reserves and their stewardship by using science and social learning (Mathevet et al. 2016).

Biosphere reserves could form the basis for a sustainable development theory revisited, confronted with reality, experimentation, and practices on the ground. Biosphere reserves should remind us that we live in a highly interconnected world, and that humans are part of the biosphere. They could also propose options and choices for solidarity and sustainability that are available today.

Responses to this article can be read online at: http://www.ecologyandsociety.org/issues/responses. $\mathrm{php} / 8812$

\section{Acknowledgments:}

This collective article was written in tribute to Robert Barbault and Jacques Weber and is dedicated to both of them.

\section{LITERATURE CITED}

Adams, W. M., R. Aveling, D. Brockington, B. Dickson, J. Elliott, J. Hutton, D. Roe, B. Vira, and W. Wolmer. 2004. Biodiversity conservation and the eradication of poverty. Science 306 (5699):1146-1149. http://dx.doi.org/10.1126/science.1097920

Amadou, B. 2006. Approach to identifying eco-functional zones: the example of the 'W' Biosphere Reserve in Niger. Pages 40-43 in M. Bouamrane, editor. Biodiversity and stakeholders: concertation itineraries. Biosphere Reserves Technical Note 1. UNESCO, Paris, France. [online] URL: http://unesdoc.unesco. org/images/0014/001465/146566e.pdf

Amadou, B., and J. Boutrais. 2012. Logiques pastorales et de conservation de la nature: les transhumances et le Parc du W (Niger, Burkina Faso, Bénin). Autrepart 60:55-76. http://dx.doi. org/10.3917/autr.060.0055

Barnaud, C., P. d'Aquino, W. Daré, C. Fourage, R. Mathevet, and G. Trébuil. 2011. Power asymmetries in companion modelling processes. Pages 117-140 in M. Etienne, editor. Companion modelling: a participatory approach to support sustainable development. Quae editions, Versailles, France.

Batisse, M. 1982. The biosphere reserve: a tool for environmental conservation and management. Environmental Conservation 9 (2):101-111. http://dx.doi.org/10.1017/s0376892900019937

Batisse, M. 1986. Developing and focusing the biosphere reserve concept. Nature and Resources 22(3).

Berkes, F., and C. Folke, editors. 1998. Linking social and ecological systems: management practices and social mechanisms for building resilience. Cambridge University Press, Cambridge, UK.

Borrini-Feyerabend, G., and O. Hamerlynck. 2010. Réserve de biosphère transfrontière du Delta du Sénégal: proposition de gouvernance partagée. Preliminary report. IUCN-UNESCOCEESP, Gland, Switzerland.

Bouamrane, M., editor. 2006. Biodiversity and stakeholders: concertation itineraries. Biosphere Reserves Technical Notes 1. UNESCO, Paris, France. [online] URL: http://unesdoc.unesco. org/images/0014/001465/146566e.pdf

Bouamrane, M., editor. 2007. Dialogue in biosphere reserves: references, practices and experiences. Biosphere Reserves Technical Notes 2. UNESCO, Paris, France. [online] URL: http:// unesdoc.unesco.org/images/0015/001591/159164e.pdf

Bousquet, F., O. Barreteau, P. d'Aquino, M. Etienne, S. Boisseau, S. Aubert, C. Le Page, D. Babin, and J.-C. Castella. 2002. Multiagent systems and role games: collective learning processes for ecosystem management. Pages 248-285 in M. A. Janssen, editor. Complexity and ecosystem management: the theory and practice of multi-agent systems. Edward Elgar, Cheltenham, UK. 
Bridgewater, P. 2016. The Man and Biosphere Programme of UNESCO: rambunctious child of the sixties, but was the promise fulfilled? Current Opinion in Environmental Sustainability 19:1-6. http://dx.doi.org/10.1016/j.cosust.2015.08.009

Brockington, D., and J. Igoe. 2006. Eviction for conservation: a global overview. Conservation and Society 4(3):424-470.

Brockington, D., J. Igoe, and K. Schimdt-Soltau. 2006. Conservation, human rights, and poverty reduction. Conservation Biology 20(1): 250-252. http://dx.doi.org/10.1111/j.1523-1739.2006.00335. $\underline{\mathrm{X}}$

Chapin, M. 2004. A challenge to conservationists. World Watch Magazine November/December:17-31. [online] URL: http:// www.worldwatch.org/system/files/EP176A.pdf

Colfer, C. J. P. 2005. The complex forest: communities, uncertainty and adaptive collaborative management. Resources for the Future and CIFOR, Washington, D.C., USA, and Bogor, Indonesia.

Collectif ComMod (M. Antona, P. D'Aquino, S. Aubert, O. Barreteau, S. Boissau, F. Bousquet, W. Daré, M. Etienne, C. Le Page, R. Mathevet, G. Trébuil, and J. Weber). 2005. La modélisation comme outil d'accompagnement. Natures Sciences Sociétés 13:165-168.

Cormier-Salem, M.-C. 1995. Paysans-pêcheurs du terroir et marins-pêcheurs du parcours. Les géographes et l'espace aquatique. L'espace Géographique 1:46-59.

Cormier-Salem, M.-C. 2006. Vers de nouveaux territoires de la conservation. Exemple des littoraux ouest-africains. Annales de Géographie 115(651):597-617. http://dx.doi.org/10.3406/geo.2006.21289

Cormier-Salem, M.-C. 2014. Participatory governance of Marine Protected Areas: a political challenge, an ethical imperative, different trajectories. Senegal case studies. S.A.P.I.EN.S. 7(2). [online] URL: http://sapiens.revues.org/1560

Daré, W., A. Van Passen, R. Ducrot, R. Mathevet, J. Queste, G. Trébuil, C. Barnaud, and E. Lagabrielle. 2011. Learning about interdependencies and dynamics. Pages 205-230 in M. Etienne, editor. Companion modelling: a participatory approach to support sustainable development. Quae editions, Versailles, France.

Deldicque, M. 2007. Dialogue in the itinerary of biosphere creation. Pages 5-20 in M. Bouamrane, editor. Dialogue in biosphere reserves: references, practices and experiences. Biosphere Reserve Technical Notes 2. UNESCO, Paris, France. [online] URL: http://unesdoc.unesco.org/images/0015/001591/159164e. pdf

Dressler, W., B. Büscher, M. Schoon, D. Brockington, T. Hayes, C. A. Kull, J. McCarthy, and K. Shrestha. 2010. From hope to crisis and back again? A critical history of the global CBNRM narrative. Environmental Conservation 37(1):5-15 http://dx.doi. org/10.1017/s0376892910000044

Etienne, M. 2006. Companion modelling: a tool for dialogue and concertation in Biosphere Reserves. Pages 44-52 in $\mathrm{M}$. Bouamrane, editor. Dialogue in biosphere reserves: references, practices and experiences. Biosphere Reserves Technical Notes 2. UNESCO, Paris, France. [online] URL: http://unesdoc.unesco. org/images/0015/001591/159164e.pdf
Fabre, M., M.-C. Cormier-Salem, I. Sylla, Z. Ould Sidaty, and S. Duvail. 2016. Mapping the ecological solidarities: migratory birds of the Transboundary Biosphere Reserve of the Senegal River Delta. African Journal of Aquatic Sciences, in press.

Fischer, J., T. A. Gardner, E. M. Bennett, P. Balvanera, R. Biggs, S. Carpenter, T. Daw, C. Folke, R. Hill, T. P. Hughes, T. Luthe, M. Maass, M. Meacham, A. V. Norström, G. Peterson, C. Queiroz, R. Seppelt, M. Spierenburg, and J. Tenhunen. 2015. Advancing sustainability through mainstreaming a socialecological systems perspective. Current Opinion in Environmental Sustainability 14:144-149. http://dx.doi.org/10.1016/j.cosust.2015.06.002

Folke, C. 2006. Resilience: the emergence of a perspective for social-ecological systems analyses. Global Environmental Change 16(3):253-267. http://dx.doi.org/10.1016/j.gloenvcha.2006.04.002

Ghimire, K. B., and M. P. Pimbert, editors. 1997. Social change and conservation: environmental politics and impacts of national parks and protected areas. Earthscan, London, UK.

Homer-Dixon, T., B. Walker, R. Biggs, A.-S. Crépin, C. Folke, E. F. Lambin, G. D. Peterson, J. Rockström, M. Scheffer, W. Steffen, and M. Troell. 2015. Synchronous failure: the emerging causal architecture of global crisis. Ecology and Society 20(3):6. http:// dx.doi.org/10.5751/es-07681-200306

Hulme, D., and M. Murphree. 2001. Community conservation in Africa, an introduction. Pages 1-8 in D. Hulme and M. Murphree, editors. African wildlife and livelihoods: the promise and performance of community conservation. James Currey, Oxford, UK.

Hutton, J., W. M. Adams, and J. C. Murombedzi. 2005. Back to the barriers? Changing narratives in biodiversity conservation. Forum for Development Studies 32(2):341-370. http://dx.doi. org/10.1080/08039410.2005.9666319

Ishwaran, N., A. Persic, and N. H. Tri. 2008. Concept and practice: the case of UNESCO biosphere reserves. International Journal of Environment and Sustainable Development 7 (2):118-131. http://dx.doi.org/10.1504/IJESD.2008.018358

Mathevet, R., F. Bousquet, C. Le Page, and M. Antona. $2003 a$. Agent-based simulations of interactions between duck population, farming decisions and hunting rights in the Camargue (southern France). Ecological Modelling 165 (2-3):107-126. http://dx.doi.org/10.1016/S0304-3800(03)00098$\underline{X}$

Mathevet, R., M. Etienne, T. Lynam, and C. Calvet. 2011. Water management in the Camargue Biosphere Reserve: insights from comparative mental models analysis. Ecology and Society 16 (1):43. [online] URL: http://www.ecologyandsociety.org/vol16/ iss1/art43/

Mathevet, R., C. Le Page, M. Etienne, G. Lefebvre, B. Poulin, G. Gigot, S. Proréol, and A. Mauchamp. 2007. ButorStar: a roleplaying game for collective awareness of wise reedbed use. Simulation and Gaming 38(2):233-262. http://dx.doi. org/10.1177/1046878107300665

Mathevet, R., A. Mauchamp, R. Lifran, B. Poulin, and G. Lefebvre. 2003b. ReedSim: simulating ecological and economical dynamics of Mediterranean reedbeds. Pages 1007-1012 in D. Post, 
editor. Integrative modelling of biophysical, social and economic systems for resource management solution. Modelling and Simulation Society of Australia and New Zealand, Townsville, Australia.

Mathevet, R., J. Thompson, O. Delanoë, M. Cheylan, C. GilFourrier, and M. Bonnin. 2010. La solidarité écologique: un nouveau concept pour une gestion intégrée des parcs nationaux et des territoires. Natures Sciences Sociétés 18(4):424-433. http:// dx.doi.org/10.1051/nss/2011006

Mathevet, R., J. D. Thompson, C. Folke, and F. S. Chapin III. 2016. Protected areas and their surrounding territory: socioecological systems in the context of ecological solidarity. Ecological Applications 26(1):5-16. http://dx.doi.org/10.1890/14-0421

MEA (Millenium Ecosystem Assessment). 2005. Ecosystems and human well-being: synthesis. Island Press, Washington, D.C., USA. [online] URL: http://www.unep.org/maweb/documents/ document.356.aspx.pdf

Oldekop, J. A., G. Holmes, W. E. Harris, and K. L. Evans. 2016. A global assessment of the social and conservation outcomes of protected areas. Conservation Biology 30(1):133-141. http://dx. doi.org/10.1111/cobi.12568

Ostrom, E. 2009. A general framework for analyzing sustainability of social-ecological systems. Science 325 (5939):419-422. http://dx.doi.org/10.1126/science.1172133

Ramutsindela, M. 2004. Parks and people in postcolonial societies: experiences in southern Africa. Kluwer, Dordrecht, The Netherlands.

Ribot, J., and A. Larson, editors. 2005. Decentralization of natural resources: experiences in Africa, Asia and Latin America. Frank Cass, London, UK.

Ruiz-Mallén, I., E. Corbera, D. Calvo-Boyero, V. Reyes-García, and K. Brown. 2015. How do biosphere reserves influence local vulnerability and adaptation? Evidence from Latin America. Global Environmental Change 33:97-108. http://dx.doi.org/10.1016/ j.gloenvcha.2015.05.002

Schlosberg, D. 2013. Theorising environmental justice: the expanding sphere of a discourse. Environmental Politics 22 (1):37-55. http://dx.doi.org/10.1080/09644016.2013.755387

Schultz, L., A. Duit, and C. Folke. 2011. Participation, adaptive co-management, and management performance in the World Network of Biosphere Reserves. World Development 39 (4):662-671. http://dx.doi.org/10.1016/j.worlddev.2010.09.014

Stoll-Kleemann, S., and T. O'Riordan. 2002. From participation to partnership in biodiversity protection: experience from Germany and South Africa. Society and Natural Resources 15 (2):161-177. http://dx.doi.org/10.1080/089419202753403337

UNESCO (United Nations Educational, Scientific, and Cultural Organization). 1996. Biosphere reserves: the Seville strategy and the statutory framework of the World Network. UNESCO, Paris, France. [online] URL: http://unesdoc.unesco.org/ images/0010/001038/103849Eb.pdf

UNESCO (United Nations Educational, Scientific, and Cultural Organization). 2002. Biosphere Reserves: special places for people and nature. UNESCO, Paris, France. [online] URL: http:// unesdoc.unesco.org/images/0012/001213/121361Eo.pdf

UNESCO (United Nations Educational, Scientific, and Cultural Organization). 2008. Madrid Action Plan for Biosphere Reserves (2008-2013). UNESCO, Paris, France. [online] URL: http:// unesdoc.unesco.org/images/0016/001633/163301e.pdf

UNESCO (United Nations Educational, Scientific, and Cultural Organization). 2013. International Co-ordinating Council of the Man and Biosphere (MAB) programme: twenty-fifth session. UNESCO, Paris, France. [online] URL: http://www.unesco.org/ new/fileadmin/MULTIMEDIA/HQ/SC/pdf/SC-13CONF-225-11 Final Report en.pdf

Voß, J.-P., and B. Bornemann. 2011. The politics of reflexive governance: challenges for designing adaptive management and transition management. Ecology and Society 16(2):9. [online] URL: http://www.ecologyandsociety.org/vol16/iss2/art9/

Weber, J. 2013. Développement viable, durable ou du rabe? Pages 50-51 in A. Euzen, L. Eymard, and F. Gaill, editors. Le développement durable à découvert. CNRS Editions, Paris, France. 